\title{
A unique journey in preserving nuclear industrial heritage
}

\author{
J. B. Gunn \\ Site Closure Project, Dounreay Site Restoration Limited, UK
}

\begin{abstract}
The Dounreay nuclear site, which was built upon a former naval airfield on the north coast of Caithness, is now being decommissioned. The nuclear journey continues with the development of decommissioning technology and the creation of a unique heritage strategy, the first for a UK nuclear site. The aim is to preserve a distinct lasting cultural legacy. The strategy took over two years to develop and includes a novel and bespoke implementation plan agreed through a programme of stakeholder involvement. The work brought together various national bodies to consider nuclear industrial heritage for the very first time and was a challenging learning experience.

A Heritage Officer was appointed to manage the implementation plan which includes; an advisory panel of heritage experts, artefacts, photographs, film, records, building recording, oral history, computer modelling, a website, academic studies, art projects, promotion and history publications. This paper covers the journey in developing the heritage strategy for Dounreay, progress with the implementation plan and the lessons that have been learned over the last five years.

Keywords: Dounreay, nuclear decommissioning, nuclear heritage, industrial heritage, nuclear history.

\section{Introduction}

During the latter half of the $20^{\text {th }}$ Century Dounreay scientists and engineers developed world class nuclear technology at the site of the UK's flagship centre for fast reactor research. The site, which was built upon a former naval airfield on the north coast of Caithness, is now being decommissioned by Dounreay Site Restoration Ltd (DSRL), on behalf the UK Government's Nuclear Decommissioning Authority (NDA).
\end{abstract}


As Scotland's largest nuclear clean-up and demolition project, the trailblazing journey continues into the $21^{\text {st }}$ Century with the development of cutting edge decomissioning technology and the creation of a unique heritage strategy, the first for a UK nuclear site (Gunn and Croft [1]). This was without precedent in securing the recognition of heritage as part of a major decommissioning programme operating under challenging project and financial conditions. The aim is to preserve a distinct lasting cultural legacy for a site which has had a dominant impact on the economic, cultural and social development of the region.

The strategy, published in 2010, took over two years to develop in conjunction with Historic Scotland and experts Atkins Heritage. This included a novel and bespoke implementation plan agreed through a programme of stakeholder involvement. The work brought together various national bodies to consider nuclear industrial heritage for the very first time and was a challenging learning experience. The approach used could act as a model for other unusual and complex industrial sites.

This paper covers the journey in developing the heritage strategy for Dounreay, progress with the implementation plan and the lessons that have been learned over the last five years.

\section{Site history}

\subsection{Pre-atomic age}

The wider area around Dounreay contains many actual elements of the prehistoric and recent past, ranging from Neolithic chambered cairns, Bronze Age burial mounds, stone circles, field systems and settlements to medieval tower houses and post-medieval farmsteads and settlements. There are three scheduled ancient monuments immediately adjacent to the nuclear licensed site. The Dounreay airfield was constructed during the Second World War as a satellite land field for RAF Twatt in Orkney. However, it was mothballed on completion in April 1944 and apart from short periods of use by the Navy as HMS Tern II and later when its accommodation blocks were used as a camp for displaced Polish servicemen, it remained essentially unused.

\subsection{Atomic construction}

The Government announced on 1 March 1954 that the proposed United Kingdom Atomic Energy Authority (UKAEA) would develop the technology for a fast breeder reactor at Dounreay in Caithness. Construction started in March 1955 and was essentially complete by 1959 . Around 180 facilities were built and the original airfield's camp was extended to accommodate around 2,000 of the 2,300 construction workers. Motherwell Bridge \& Engineering Co Ltd built the iconic sphere that housed the original Dounreay Fast Reactor (DFR).

The Dounreay licensed site, an area of 55 hectares, was a unique nuclear "park" in that it had all the facilities for completing a nuclear fuel cycle for the DFR and the Dounreay Materials Testing Reactor (DMTR), [fig. 1]. Such was 


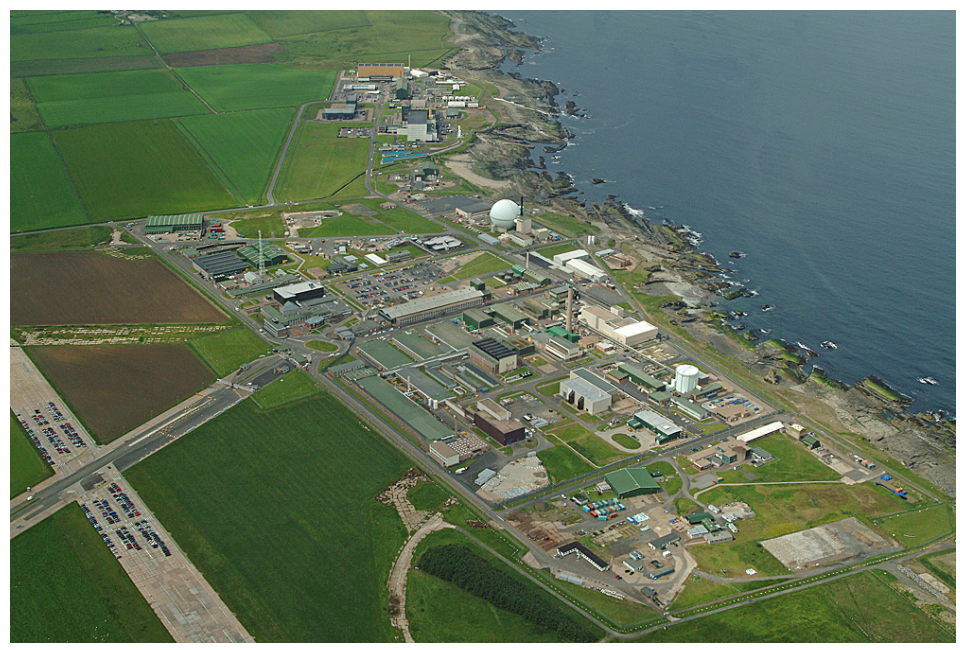

Figure 1: $\quad$ The Dounreay nuclear site on the north coast of Scotland.

the national interest, the first public open day held in May 1957, attracted around 7,500 people.

The number of UKAEA employees settled at around 2,300 with half being incomers to the county and they became known as the "Atomics". The population of the nearby town of Thurso nearly tripled from 3,200 to 9,000. Education, housing, infrastructure, leisure, social and welfare facilities all rapidly expanded. The number of shops, hotels, café's, bars and restaurants swiftly increased to take advantage of the spending power of the Dounreay workers, whose wages were well above the local average. Social integration was a potential major issue, but on the whole it was a remarkable success.

\subsection{Operating years}

Dounreay and Scotland's first self sustaining nuclear chain reaction, known as criticality, happened on 13 August 1957 within a small scale, uranium solution experimental cell. DMTR went critical on 24 May 1958 and was Scotland's first operating reactor. The DFR operated from 14 November 1959 to 23 March 1977. In 1962 it became the first fast reactor in the world to supply electricity to a national grid and was the most powerful fast reactor in the world at the time, [fig. 2]. The success of DFR led to the building of a much larger Prototype Fast Reactor (PFR) which operated from 3 March 1974 to 31 March 1994 and could produce $250 \mathrm{MW}$ of electricity, enough to power a city the size of Aberdeen. It was successful in meeting its aim of developing knowledge about the long term reliability, safety and economics of fast reactors for designing future commercial-sized fast reactors. 


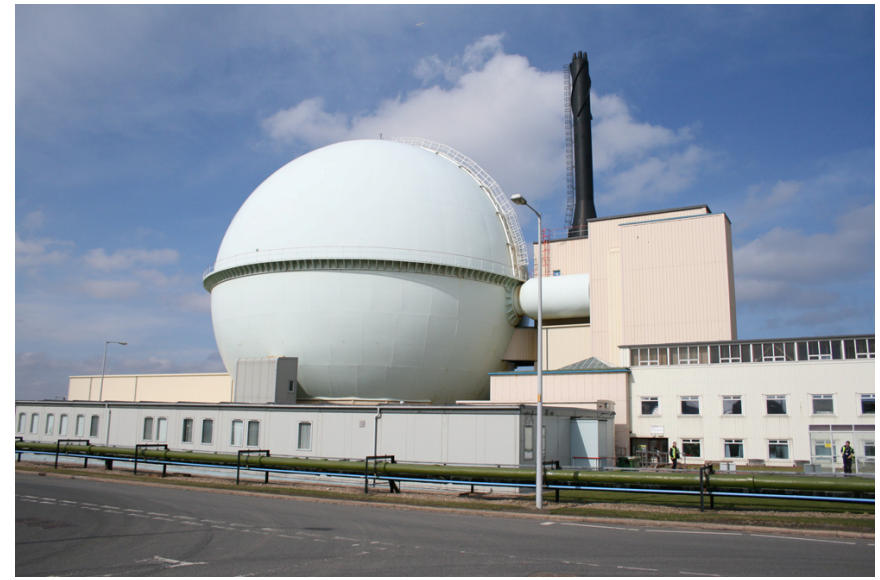

Figure 2: $\quad$ The Dounreay fast reactor (DFR).

\subsection{Decommissioning years}

In 1988 the UK Government decided to terminate the fast reactor programme and the last reactor (PFR) shutdown in 1994. Since 2000 the site has concentrated solely on decommissioning tasks. Over 100 facilities have been demolished and most will be gone by c2022. Dounreay's decommissioning work is proving be equally challenging and the site's 2,000 workers are again leading the world in developing new technologies and areas of expertise.

\section{Heritage strategy development}

Historic Scotland showed an interest in listing the DFR sphere over a period of years and visited the site in 2007. Together with the National Museum of Scotland they have indicated that Dounreay's heritage was of national importance and should be captured, preserved and celebrated. It was agreed that a strategy covering all heritage aspects would be produced, which would also serve to underpin any decision about the sphere.

With limited internal heritage expertise, it was decided to invite bids for a commercial contract to produce a strategy. There were a lot of interested parties and Atkins Heritage was selected in spring 2008. Such work had never been done for a complete nuclear site before and it was a steep learning curve for everyone involved. Working closely with local and national heritage organisations, particularly Historic Scotland, the strategy took over two years to produce and was developed in line with best practice approaches to conservation management. The report incorporates feedback from public consultation and includes a foreword of endorsement by Historic Scotland's Chief Inspector. The work was comprehensive and included a gazetteer, reviews of the local visitor/tourist market and existing worldwide nuclear and energy visitor attractions. The report can be accessed via the Dounreay website (DSRL [2]). 
The report's chapters comprise of; an executive summary, introduction, understanding Dounreay, statement of values, creating a cultural legacy, options, appendices, figures and photographs.

A programme of stakeholder involvement was held over 12 weeks. The objective was to reach a consensus view on the totality of a heritage strategy which was acceptable to stakeholders. Before launching the stakeholder process, the following activities were organised:

- meetings with Historic Scotland, National Museum of Scotland and the local museum, Caithness Horizons, about the content of the strategy

- a presentation and exhibition at a Thomas Telford event in Wick (Celebration of Industrial Archaeology in conjunction with the Institute of Civil Engineers)

- regular heritage articles published in the Dounreay News, the site newspaper

- various articles published on the site website and in the local and national press.

- regular updates at the Dounreay Stakeholder Group (DSG) meetings \& its Environment sub-group, plus an information display at a DSG public meeting.

The engagement process was officially launched in December 2009 and finished in March 2010. During that time, DSRL:

- provided presentations to site staff and contractors.

- designed a dedicated webpage on the Dounreay website about the engagement process which enabled the public to view/download the full draft strategy document, an executive summary, a newsletter and an online electronic questionnaire. In addition, numerous articles were posted on the website's front page about the engagement process, with hyperlinks to the heritage webpage.

- held information displays in the site's central restaurant and placed copies of the heritage newsletter in tea bars around the site.

- $\quad$ sponsored a High School debating competition on the future of the DFR sphere.

- held a workshop in Edinburgh with interested national heritage organisations, including Historic Scotland, National Museums Scotland, Royal Commission on the Ancient and Historical Monuments of Scotland, Highland Council, English Heritage \& Welsh Heritage representatives.

- held a workshop in Thurso with interested local organisations, including Caithness Horizons museum, Caithness \& North Sutherland Regeneration Partnership, North Highland Tourism, Caithness Chamber of Commerce, National Nuclear Archive, \& Dounreay Stakeholder Group representatives.

- sent over 80 invitations to local community groups offering presentations. Gave presentations to the Dounreay Retirement Fellowship and two Community Councils. 
- distributed an e-bulletin to 1,400 registered stakeholders with website link to heritage strategy and questionnaire.

- $\quad$ sent over 800 newsletters/questionnaires to local addresses.

- distributed an electronic Christmas card to 1,400 registered stakeholders with heritage theme and reminder to complete questionnaire.

- displayed information in Caithness Horizons museum and DSRL's public information office in Thurso over the whole 3 month period.

- $\quad$ placed advert in local newspaper.

- $\quad$ posted reminders to staff on the site's intranet noticeboard.

- published articles in the local press and in Dounreay News, the site newspaper.

- $\quad$ sent details to the Caithness Community website (Caithness [3])

The large effort to generate interest was rewarded with a healthy 38 questionnaires being returned. In summary, 30 (79\%) agreed with the broad approach to heritage issues and $21(55 \%)$ didn't want the DFR sphere to be demolished. The overall strategy remained unchanged after reviewing the responses, i.e. demolition of all non-functioning facilities, including the DFR sphere and to explore all avenues to capture, preserve and celebrate Dounreay's cultural heritage for public benefit. The justification for dismantling the DFR sphere is based on a number of factors:

- the prohibitive high cost of removing all of the radioactive contamination from the sphere shell

- the high cost of painting the sphere every decade (c£0.5M) to maintain its condition and avoid turning into a rusting eyesore

- minimising the cost burden on future generations

- $\quad$ security and safety issues that will limit public access

- the removal all of the plant and equipment due to contamination will leave little evidential and technological value

- the very limited local visitor and tourism market leads to no viable selfsustaining end use

- $\quad$ value for money to the taxpayer and affordability in the current state of government finances

The strategy is available on the Dounreay website within the site closure and heritage section (DSRL [2]). DSRL was already implementing a number of components of the strategy as a part of its normal business and to expand the activities and act as a focal point, DSRL appointed a Heritage Officer to manage an implementation plan.

\section{Implementation plan}

\subsection{Plan details}

The heritage implementation plan covers the following topics;

1. Policy and strategy

2. Procedures 
3. Guidance notes

4. Archives

5. Advisory panel

6. Collections

7. Oral history

8. Training and development

9. Benchmarking and learning from others

10. Sharing knowledge

11. Building recording

12. Publications

13. On line/virtual material

14. Recording decommissioning

15. Communications

16. Innovation

17. Opportunity with commemoration

18. Opportunity with academic studies

19. Opportunity with conferences

20. Opportunity with a national exhibition

\subsection{Progress}

The strategy was issued in September 2010, but some of the implementation plan actions have been a normal part of business for years. Archiving started from the very beginning back in 1955 for records, photographs, drawings and films. There are around a million items. Project teams and the Communications department have recorded decommissioning progress via photos, film, news articles and reports for many years. A heritage policy, guidance notes on capturing oral history and collecting objects, together with a job description, technical competency requirements and a management procedure for the part-time Heritage Officer role, have all been produced. The Heritage Officer role includes;

- maintaining close links with the local and national museums to find out what object types are desirable to preserve

- $\quad$ an active member of the Scottish Transport and Industry Collections Knowledge (STICK) network

- $\quad$ presentations about Dounreay's heritage journey to STICK members and parties involved in the decommissioning of the Welsh Trawsfynydd nuclear power station, including the Welsh Government

- $\quad$ producing a summary of Dounreay's history for an information leaflet given to visitors to the Dounreay exhibition at the Caithness Horizons museum, [fig. 3].

- regularly featuring in local, regional and national press, radio and TV media, promoting Dounreay's heritage work

- $\quad$ successfully passing a heritage course at the Open University 


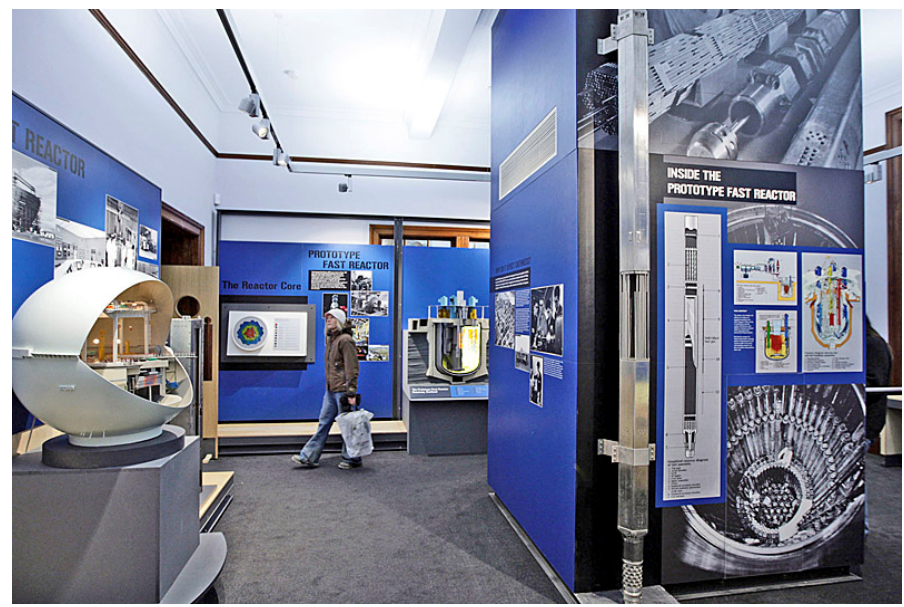

Figure 3: The Dounreay exhibition within Caithness Horizons museum.

\subsubsection{Opportunities}

During the development of the strategy, opportunities were identified that DSRL would not be able to fund nor deliver, as part of the site activities. However, these opportunities will be pursued by working with others. The opportunities are;

- $\quad$ funded academic study - DSRL will provide support to an academic body if there is an interest to consider an academic study/qualification on the subject of Dounreay and its heritage.

- off-site exhibition - The option was to explore the possibility of developing a major off-site gallery relating to Dounreay and/or the wider nuclear industry.

- international conference - The development of an international scale conference relating to nuclear heritage management has the potential to advance understanding in this field.

- commemorative installation - The installation of a commemorative feature or 'gate guardian' following building demolition.

There has already been some success with academic study. A student at the University of Edinburgh completed an MSc in 2011 with a dissertation about the role of National Museums Scotland in the Dounreay heritage strategy (Davidson [4]).

\subsubsection{Advisory panel}

An advisory panel of experts from Historic Scotland, the National Museum of Scotland, the Royal Commission on the Ancient and Historic Monuments of Scotland and Caithness Horizons, has been constituted to give DSRL advice on heritage matters and for DSRL to give factual information for exhibitions. The Panel has met annually since 2010 . 


\subsubsection{Object collection}

Nearly 250 objects have been collected by the Heritage Officer since 2008 and the majority have been donated to the National Museum of Scotland and Caithness Horizons. Two Dounreay objects are presently on display at the National Museum in Edinburgh and Caithness Horizons has a permanent exhibition about Dounreay, [fig. 3]. Museums are not the only outlet for preservation, two unique fire engines adapted to fight sodium fires at the two fast reactor complexes were donated to vintage vehicle preservation groups.

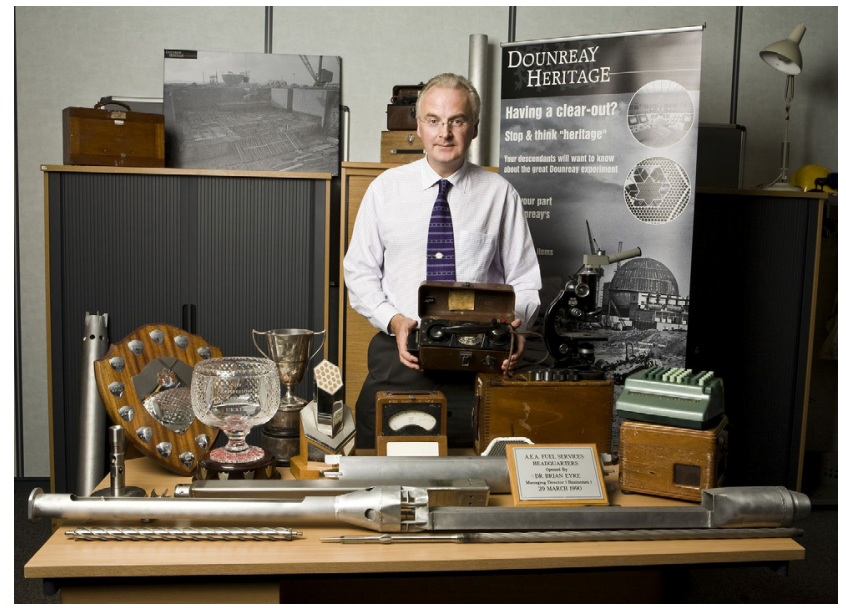

Figure 4: DSRL heritage officer James Gunn with a selection of objects.

\subsubsection{Oral history}

A pilot project to record the memories of six people was completed in March 2012 by the Heritage Officer. The number of people directly employed since construction began in 1955 is around 11,500 and the number of contractors is thought to be similar, so there is a large audience available for capturing memories. With the people involved in the construction and initial operating years now in their $80 \mathrm{~s}$ or $90 \mathrm{~s}$, time is running out to capture the exciting and expectant atmosphere of the beginnings of the nuclear power era.

All DSRL staff who leave employment are given a "capturing memories" form before they leave or retire. The form has five questions and gives the opportunity to describe their most memorable moments of their time at Dounreay. The return rate is around $15-20 \%$.

\subsubsection{Publications}

Help and advice was given to the authors of two history books published in 2008 and 2009. A journalist compiled a history of Dounreay's first 50 years (Paterson [5]) and the pupils of Thurso High school produced a booklet about the effect that Dounreay had on Caithness (Thurso High [6]). It includes a DVD of filmed interviews with local people. Two other history books were produced in the 1990s by Dounreay employees (Sutherland [7], Cashmore [8]). Information is 
being compiled by the Heritage Officer with the aim of publishing a book around the time the site's buildings will be virtually gone and the land restored (circa 2022).

DSRL produced an album showing photographs of site visits by royalty and the project team had the honour of presenting it to Her Majesty the Queen during a private audience at Balmoral in August 2011. Copies of the album can be seen at Caithness Horizons and at the Castle of Mey on the north coast of Caithness, the late Queen Mother's holiday residence for 50 years.

\subsubsection{On line and virtual material}

A section of Dounreay's website is dedicated to the site's history and cultural heritage (DSRL [2]). Many photos appear in the website's image library and on social media (Flickr [9]). The Caithness community website also has lots of history information (Caithness [3]). Many of the decommissioning projects have produced 3D computer models of buildings and plant, in order to help the complex and challenging dismantling work. These are being collated by the design office as a useful building record alongside drawings. However, the issue for the future will be the need to regularly convert/update the programmes so that the latest computers can read the software and display the images.

The present day decommissioning activities are the future's heritage and these are being digitally captured for both still and moving images and shown to the public via the website and a dedicated Dounreay TV channel (Youtube [10]). The Communications team also keeps the public informed of latest events via Facebook (Facebook [11]) and via tweets on Twitter (Twitter [12]).

\subsubsection{Innovation}

The current technology of combining laser scanning output with digital photographs to produce highly accurate $3 \mathrm{D}$ images of buildings is an innovative way of recording buildings. Laser scans have been taken of the ruinous Dounreay Castle and facilities within the Prototype Fast Reactor complex.

A Dundee college acquired an arts grant to produce a short artistic film about Dounreay's heritage (Dunlop [13]). The film uses split screen technology to show original film from the 1950s and 60s alongside present day footage of the same scenes. The film received critical acclaim and has been shown at venues around the UK and Europe throughout 2011 and 2012.

\section{Lessons learned}

The heritage project started in 2007 and the lessons learned over the subsequent 5 years are summarised as:

1. To initially generate staff interest, organise a small roadshow and stage lunchtime exhibitions at each major work area.

2. Have a permanent on-site display of objects and photos that is open to staff, to maintain interest. Photograph albums generate the most interest, closely followed by film footage. 
3. Maximise publicity by having a regular stream of heritage news stories for the site newsletter and local press. Most people are interested in heritage and it is viewed as a good story. Many ex-employees have donated objects after reading news stories.

4. Involve building managers or staff with long experience, in identifying objects with historic significance. Most objects are hidden away from general view.

5. Identify objects well in advance of plant stripout, to have time to plan transportation to a store and avoid hindering the decommissioning programme.

6. Take a photo and write down all the background details of an object to maximise its value, e.g. a photo with date, location, names \& reason why taken, is more valuable and interesting than one with no details.

7. Any database with the details of objects collected should preferably be the same as used by the final destination museum for ease of data transfer.

8. When people donate or loan a personal object, you must get them to sign a form to that effect. This avoids any ownership issues in the future, particularly if immediate family claim ownership after the death of the person. Museums will not accept objects if ownership rights are unclear.

9. Have a dedicated lockable store for collection of objects to avoid inadvertent disposal by others.

10. Check and monitor everything that leaves the site, even if not from radiation controlled areas, to ensure no contaminated items are released into the public domain. Be extra cautious with objects that have fans drawing air into internals. Also, check for any hazardous materials, such as asbestos or PCBs.

11. Items from radiation/contamination controlled areas have to be treated with extreme caution. Dispose if not $100 \%$ sure about its history and internal cleanliness.

12. Involve key stakeholders in all stages of producing a strategy or action plan, to increase probability of being comprehensive and getting it right first time.

13. Explore all avenues for external funding, not just obvious ones, e.g the arts, education or special socio-economic regeneration funds.

14. Museums are not the only avenues for donating objects, specialist preservation groups can be used, e.g. vintage vehicle club.

15. The resources of an existing local heritage group or forming a new dedicated volunteering group, is a possible route to capturing oral history at low cost and an avenue for community type grants.

16. Capture oral history via good quality digital state recorders or better still, digital video, to produce crystal clear recordings.

17. Success is much easier if the senior management team show visible support and the heritage officer or project team is enthusiastic about heritage. 


\section{Conclusions}

Heritage management in the nuclear industry is in its infancy and Dounreay is the first UK site to develop a heritage strategy for a whole site. Dounreay was the UK's centre of fast reactor research and development and is recognised as being of national historic importance. The challenging and unique journey in producing a heritage strategy encompassing the whole site was supported by contracting experts Atkins Heritage to initiate the task. A cost effective, consensual and credible process of recording and preserving aspects of the site's heritage was implemented in the middle of a major decommissioning programme. Contributions from local and national heritage bodies, as well as staff and the community, helped to develop the project during a period of over two years. The continued involvement of heritage bodies, via an advisory panel, to provide advice on the strategy's implementation plan, is an excellent example of successful collaboration between industry and the private and public sector. The innovative work may provide a model of wider applicability to similarly unique and complex industrial sites throughout the UK and elsewhere.

\section{References}

[1] Gunn, J.B. and Croft, A., Dounreay Heritage Strategy, Dounreay Site Restoration Limited, August 2010.

[2] Dounreay Site Restoration Limited website, www.dounreay.com

[3] Caithness community website, www.caithness.org

[4] Davdison, E., Networks of nuclear heritage: The role of National Museums Scotland in the Dounreay heritage strategy, MSc science and technology studies, school of social and political science, the University of Edinburgh, August 2011.

[5] Paterson, W., 50 Years of Dounreay, ISBN: 978-1-871704-37-2, North of Scotland Newspapers, Wick, 2008.

[6] Pupils of Thurso High School, Fae fields to fuel - Caithness, before and after Dounreay, Thurso High School, 2009.

[7] Sutherland, I., Dounreay - An experimental reactor establishment, Iain Sutherland, Wick, 1990.

[8] Cashmore, S., Dounreay - The illustrated story, ISBN 1871704 21 9, North of Scotland Newspapers, Wick, 1998.

[9] Flickr, www.flickr.com/photos/dounreay

[10] Youtube, www.youtube.com/user/DounreayTV

[11] Facebook, www.facebook.com/Dounreay

[12] Twitter, www.twitter.com/DounreayPress

[13] Dunlop, G., Atom town: Life after technology (film), Duncan of Jordanstone College of Art and Design, Dundee, 2011. 